DOI: $10.22559 /$ folklor.878

folklor/edebiyat, cilt:25, sayı:98, 2019/2

\title{
Azerbaycan Türklerinin Atasözlerine Yansıyan Toprak Olgusu'
}

\section{Earth Phenomenon which has Reflected the Proverbs of Azerbaijan Turks}

\section{Aslı Büyükokutan Töret ${ }^{2}$}

\begin{abstract}
$\ddot{O} z$
Ait olduğu toprağın, temel değer ve yargılarını, düşünce sistemlerini, din ve ahlâk anlayışlarını belli bir kalıp içinde söyleyen atasözleri, diğer Türk topluluklarında olduğu gibi, Azerbaycan Türkleri için de önemli sözlü kültür ürünlerindendir. Belli bir kompozisyon içerisinde, akılda tutmayı kolaylaştıran edebî sanatlardan da faydalanarak ortaya konulan atasözleri, çeşitli konu ve temalarda olabilmektedir. Bu bağlamda toprak, Azerbaycan Türklerinin duruş, tavır ve zihniyetlerini dışa vuran özlü sözler olarak merak uyandırmaktadır. Makalede, Azerbaycan Türklerinin atasözlerine yansıyan toprak olgusu üzerinde, örneklerden hareketle durularak, bu olgunun ağırlıklı olarak hangi unsurlar üzerinde yoğunlaştığı sorgulanmıştır. Atasözü örnekleri, Cəlal Bəydili (Məmmədov) tarafından hazırlanan Atalar Sözü, Bəhlul Abdulla'nın 2001 yılında yayımlanan Azərbaycan Şifahi Xalq Odəbiyyatı ve Göksel Öztürk tarafindan hazırlanan Azerbaycan Atasözleri ve Deyimleri adlı yüksek lisans tezinden alınmıştır. Çalışma ile Azerbaycan Türklerinin toprakla ilgili atasözlerinin; yaşanılan yer (vatan) anlamı etrafında yoğunlaştığı, vatanın güzel-

Bu makale, 13-15 Ekim 2017 tarihlerinde "T.C. Kültür ve Turizm Bakanlığı, Cumhuriyet Üniversitesi ve Motif Vakfı" iş birliği ile Sivas'ta düzenlenen Halk Kültüründe Toprak Uluslararası Sempozyumu'nda sunulan

2 Doç.Dr., Eskişehir Osmangazi Üniversitesi Fen-Edebiyat Fakültesi Türk Dili ve Edebiyatı Bölümü.
\end{abstract} bildirinin, genişletilmiş ve düzenlenmiş hâlidir. abuyukokutan@hotmail.com 
liği, kutsallığı, vatana sahip çıkmak gerektiği, vatandan ayrı kalma acısı, toprağa emek vermek gerektiği gibi konuları öne çıkardığı tespit edilmiştir. Bunun yanı sıra toprağın, canlı bir unsur olarak algılanması, bolluk, bereket, zenginlik kaynağ1 olması, toprağı işlemenin gerekliliği gibi konuların vurgulandığg görülmüsştür. Tespit ve değerlendirmelerin, Azerbaycan Türklerinin geleneksel dünya görüşleriyle ilgili bilgilerimize toprak, vatan ve emek bağlamında katkıda bulunması beklenmektedir.

Anahtar sözcükler: Azerbaycan, atasözü, toprak, vatan, emek

\begin{abstract}
The proverbs that say the earth, the basic values and judgments, the systems of thought, the concepts of religion and morality in a certain pattern are important verbal cultural products for the Turks of Azerbaijan as they are in other Turkic communities. The proverbs that can be found in a certain composition by taking advantage of literary arts that make it easier to keep in mind can be found in various subjects and themes. In this context, the land arouses curiosity as the core words that outstrip the attitudes and mentalities of the Azerbaijani Turks. In this paper, it was questioned on the elements of Azerbaijani Turks which were mainly concentrated on the phenomenon of land reflected in the proverbs. Proverb samples were extracted from "Atalar Sözü" prepared by Cəlal Bəydili (Məmmədov), “Azərbaycan Şifahi Xalq Odəbiyyatı” published by Bəhlul Abdulla in 2011 and the master thesis “Azerbaycan Atasözleri ve Deyimleri” prepared by Göksel Öztürk. The study shows that the proverbs of the Azerbaijani Turks about the soil; It has been determined that the subjects emphasized around the meaning of the place of life (homeland), the beauty of the country, the sanctity of the country, the necessity of owning the patriotism, the suffering of separating the citizens, and the laboring of the land should be emphasized. In addition to this, it has been seen that subjects such as the perception of the soil as a living element, abundance, abundance, being a source of wealth, necessity of processing the land are emphasized. It is expected that the assessments and evaluations will contribute to the knowledge of the Azerbaijani Turks about the traditional worldviews in the context of land, homeland and labor.
\end{abstract}

Keywords: Azerbaijan, proverb, land, homeland, labor

\title{
Giriş
}

Türkiye Türkçesinde ağırlıklı olarak “atasözü”, "atalar sözü”, "mesel” gibi terimlerle karşılanan atasözleri, halk edebiyatının ortak türlerindendir. Türk toplulukları arasında farklı terimlerle anılmakla birlikte Azerbaycan Türkleri, Türkiye Türkçesindeki gibi "atalar sözü” ya da "eskiler sözü” terimlerini kullanmaktadırlar (Elçin, 1997: 413-424; Oy, 1972: 225-241; Çobanoğlu, 2004; Aça, 2011 vd.). Belli bir kalıp ve kompozisyon içerisinde, akılda tutmayı kolaylaştıran edebî sanatlardan da faydalanarak ortaya konulan atasözlerine, Türkçenin en eski yazılı metinleri olan Orhun Yazıtları, Divânü Lügâti’t Türk ve Uygur dönemi yazılı 
metinlerinde de rastlanmaktadır (Aça, 2009: 484). Ait olduğu toprağın, temel değer ve yargılarını, düşünce sistemlerini, din ve ahlâk anlayışlarını yansıtan atasözleri, çeşitli konu ve temalarda olabilmektedir. Bu açıdan kolektif aklı yansıtan, "muhakeme edilemeyecek" kadar "mutlak" doğru olarak kabul edilen atasözleri (Çobanoğlu, 2004: 9-10) ele aldığı konuları olabildiğince sade ancak derin bir şekilde anlatmaktadır (Beydili, 2004: 4-6). Bu bağlamda toprak, Azerbaycan Türklerinin uzun bir gözlem ve deneme sonucunda, hakkında birtakım inanış, düşünce ve çıkarımlara vardıkları olgulardandır.

Bedii-estetik yönü yüksek olan atasözleri (Beydili, 2004: 7), bağlamdan bağımsız olarak kullanılmamaktadır. Bir diğer ifadeyle atasözleri, diğer halk edebiyatı türlerinin içinde ya da günlük konuşmalarda söz arasında yer alırlar (Oy, 1972: 53). Yani, “... atalar sözü, masal ya da türkü gibi, durup dururken tek başına söylenmez... Bir atalar sözünün söylenmesi için ise belli bir vesilenin çıkmış olması gereklidir..." (Boratav, 1988: 119). Büyük oranda manzum yapıda olan atasözlerinde (Elçin, 1993: 626), kelime oyunlarından kaçınılır (Boratav, 1988: 119). Atasözlerinin çoğu bir, iki cümleden ibarettir (Aksoy, 1984: 19-21). Bunun yanı sıra atasözleri, içinde yer aldığı topluma özgüdür (Altaylı, 2010: 126). Bir toplum tarafindan oluşturulan atasözleri, söylendiği kalıp ve kelimeler hâlinde donup kalmışlardır, içindeki kelimeler ve cümle yapısı değiştirilemez (Aksoy, 1984: 19). Bu açıdan bakıldığında toprak, Azerbaycan Türklerinin duruş, tavır ve zihniyetlerini dışa vuran özlü sözler olarak merak uyandırmaktadır.

Makalede, Azerbaycan Türklerinin atasözlerine yansıyan toprak olgusu üzerinde, örneklerden hareketle durularak, bu olgunun ağırlıklı olarak hangi unsurlar üzerinde yoğunlaştığı sorgulanacaktır. Yapılan değerlendirmelerle, Azerbaycan Türklerinin toprakla ilgili atasözlerinin; yaşanılan yer (vatan) anlamı etrafında yoğunlaştığı, vatanın güzelliği, kutsallığı, vatana sahip çıkmak gerektiği, vatandan ayrı kalma acısı, toprağa emek vermek gerektiği gibi konuları öne çıkardığı ortaya konulacaktır. Bunun yanı sıra toprağın, canlı bir unsur olarak algılanması, bolluk, bereket, zenginlik kaynağı olması, toprağı işlemenin gerekliliği gibi konuların vurgulandığı belirtilecektir. Tespit ve değerlendirmelerin, Azerbaycan Türklerinin geleneksel dünya görüşleriyle ilgili bilgilerimize toprak, vatan ve emek bağlamında katkıda bulunması beklenmektedir.

Çalışmada yararlanılacak atasözü örnekleri, Cəlal Bəydili (Məmmədov) tarafından hazırlanan Atalar Sözü, Bəhlul Abdulla’nın 2001 yılında yayımlanan Azərbaycan Şifahi Xalq Odabiyyatı ve Göksel Öztürk tarafından hazırlanan Azerbaycan Atasözleri ve Deyimleri adlı yüksek lisans tezinden alınmıştır. Ancak asıl konuya geçilmeden önce, Türk dilinde ve bu bağlamda Azerbaycan Türkçesinde toprak ve toprak anlamını içinde barındıran yer sözcükleri hakkında, anlam, değer, kullanım, konu ve işlev bağlamında kısaca durmakta fayda vardır.

\section{Toprak}

Toprak kelimesi, Türkçenin en eski yazılı metinlerinden bugüne küçük ses değişimleriyle birlikte gelmiş ve hemen hemen bütün Türk lehçelerinde korunmuştur. Öyle ki kelime Eski Türkçede "toprak", Orta Türkçede "toprak”, Türkmen, Kazak ve Uygur Türkçesinde "toprak”, Azerbaycan Türkçesinde "torpag̀”, Kırgız Türkçesinde "topurak”, Yakut Türkçesinde “toburah”, Başkut Türkçesinde “tuprak”, Özbek Türkçesinde “tupråk” şeklinde görülmektedir (Gülensoy, 2011: 914-915, Karşılaştırmalı Türk Lehçeleri Sözlüğü, 1991: 898). 
Türkçe Sözlük'te (2011: 2371), toprak kelimesinin temel anlamı "Yer kabuğunun, toz durumuna gelmiş türlü kütle kırıntılarıyla, çürümüş organik cisimlerden oluşan ve canlılara yaşama ortamı sağlayan yüzey bölümü” olarak ifade edilirken, Azerbaycan Türkçesinde, "Planetimizin bitki aləminin inkişaf etdiyi üst qatı. Yer qabığının tərkibinə daxil olan yumsaq, dənəvər, tündqonur rəngli maddə” şeklinde tanımlanmaktadır (Orucov vd., 2006: 359).

Türkiye Türkçesinde kelimenin mecaz anlamı olarak "ülke" karşılığ 1 da verilmektedir (Türkçe Sözlük, 2011: 2371). Sir Gerard Clauson, kelimenin mecazi olarak "ülke, vatan" anlamında bütün Türk lehçelerinde korunduğunu belirtmektedir (Clauson, 1972: 443). Azərbaycan Dilinin İzahlı Lüğəti'nde de toprak kelimesinin mecaz anlamı "vətən, yurd, el" olarak verilmektedir (Orucov vd., 2006: 360).

Türk dilinin en eski yazılı metinleri olan Orhun Abideleri'nde toprak anlamında "yaġız yir” (Ergin, 2000: 8), Divanü Lûgat-İt-Türk'te “yagız yer” (Atalay, 2013: 10), Kutadgu Bilig’te "yaġız yir" (Arat, 2008: 92) ifadeleri geçmektedir. Türkiye Türkçesinde yer kelimesinin sözlük karşılığı şu anlamları kapsamaktadır: "1. Bir şeyin, bir kimsenin kapladığı veya kaplayabileceği boşluk, mahal, mekân. 2. Gezinilen, ayakla basılan taban. 3. Bulunulan, yaşanılan, oturulan bölge. 4. Durum, konum, vaziyet. 5. Ülke. 6. Görev, makam. 7. Önem. 8. İz. 9. Üzerine yapı kurulmaya elverişli arazi, arsa. 10. Ekime elverişli toprak parçası, arazi" (Türkçe Sözlük, 2011: 2575). Dikkat edileceği üzere kelimenin “toprak” anlamındaki karşılığ 1 9. ve 10. maddelerde belirtilmiştir. Azerbaycan Türkçesinde ise yer kelimesinin karşılığ1 olarak şunlar verilmektedir: "1. Üzərində sakin olduğumuz planet. 2. Quru (su səthi müqabili). 3. Yer qabığının üst qatı; torpaq. 4. Üzerinde dayandığımız ve hərəkət etdiyimiz sahə. 5. Kənd təsərrüfatı məqsədləri üçün istifadə edilən (yaxud edilməyən) torpaq sahəsi. 6. Ölkə, ərazi, vətən, diyar, məmləkət ..." (Orucov vd., 2006: 580).

Bu bağlamda, toprak ve yer kelimelerinin, Türkiye Türkçesi ve Azerbaycan Türkçesinde, “Üzerinde yaşam sürülen mekân” anlamında kullanıldıklarını söylemek mümkündür. Mitolojide toprak, "Tanrılık nitelik taşıdığına inanılan yer kabuğu”dur (Hançerlioğlu, 2013: 516). Mircea Eliade'nin ifade ettiğine göre; yer anlamında kullanılan pek çok sözcüğün kökeni mekânla ilgili izlenimlerden kaynaklanmaktadır: "yer," "geniş," "arazi"; "katı," "kara" vb. Yerin toprağa bağlı olarak değer kazanması, özellikle de tarım faaliyetleriyle gerçekleşmiştir. O güne kadar "yer tanrıları" olarak adlandırılanlar daha çok belli bir ortamın kozmik tanrıları olarak varlık bulmuşlardır (Eliade, 2000: 248). Yerin sahibi, tüm canlı varlıkların kaynağı, çocukların bekçisi ve ölülerin gömüldükten sonra dinlendikleri, yenilendikleri ve sonra onun kutsallığı sayesinde yaşama yeniden döndükleri rahim olma işlevleriyle toprak kutsal kabul edilmiş ve etrafında çeşitli ritüeller oluşmuştur (Eliade, 2000: 262-263).

Proto-Türk ve Türklerin en eski kozmolojisine göre, "gök" ve "yir-sub/v" (yer-su: yeryüzü), kâinatın bütün tezahürlerini temsil eden, birbirine zıt, fakat birbirini tamamlayan bir çifttir (Esin, 2001: 19). Mitik metinlerde, kozmogonik ve dişil bir unsur olarak algılanan toprak; "Toprak Ana", "Yeryüzü Ana”, "yer tanrıçaları" kavramlarıyla simgelenmiştir (Korkmaz, 2004: 143). Öyle ki, tarımla ilgili pek çok inanış, "Toprak bizim annemiz, gök bizim babamız. Gök toprağı, yağmurla döller ve yer tahıl ve bitki verir” düşünesi etrafında toplanmıştır (Eliade, 2000: 245). Varoluş tasarımlarında dişil bir güç olan toprak, aynı zamanda insanın yaratıldığı temel unsur, dolayısıyla yaşam döngüsünün başlangıç maddesidir (Ögel, 
1998: 487). Annemarie Schimmel (2002: 24), “Kadınlar sizin tarlalarınızdır..." ayeti ile bu

durumun, İslami gelenekte de kabul gördüğünü belirtmektedir. Yine toprak ve ölüm olgusu arasında güçlü bir ilişki söz konusudur (Eren, 2012: 259-271).

Görüldügü gibi Türk kültüründe toprak; merkezde yer alma, insanın yaratılışındaki hammadde olma, analık vasfiyla üretme, hayat verme, koruma, bağrına basma, bolluk ve bereket saçma, yurt olma işlevleriyle önemli bir unsurdur (Çağlar, 2008). Bunun yanı sıra beslenme, yiyecek yapımı ve korunması, mutfak eşyası yapımı, ev yapımı ve onarımı, temizlik, ilaç yapımı ve sağaltma işlevleriyle de ön plandadır (Kasapoğlu Akyol, 2012: 316-333). Toprak ve toprak anlamını içinde barındıran yer sözcükleri üzerinde, anlam, değer, kullanım, konu ve işlev bakımından ayrıntılı açıklamalarda bulunmak, elbette mümkündür. Kanaatimizce, toprakla ilgili açıklamaları, Azerbaycan Türklerinin atasözleri üzerinden sürdürmekte yarar vardır.

\section{Toprak olgusu ve Azerbaycan Türklerinin atasözleri}

İşlevciliğin genel aksiyomları hakkında Bronislaw Malinowski'nin ifade ettiği üzere, "Kültür bir nesneler, eylemler ve zihniyetler sistemidir, bu sistem içerisinde her parça bir amaca hizmet eden bir araç olarak bulunur" (Malinowski 1992: 21). Bu bağlamda, Azerbaycan Türklerinin atasözleri, toplumun tarihi, düşünce yapısı, geleneksel dünya görüşüyle ilgili bilgilerimize toprak, vatan ve emek bağlamında katkı sağlama işleviyle, kültürün önemli bir aracı konumundadır. En büyük hikmetleri en sade ve en derin şekilde anlatabilen atasözleri (Beydili, 2004: 4-6), toprağın önem ve değerini yeni nesle aktarması açısından işlevseldir.

Meşruluğu toplum tarafından onaylanmış olan atasözlerine, bir fikri ya da hükmü onaylamak ya da tenkit etmek amacıyla başvurulmaktadır (Çobanoğlu, 2004: 7). Ağırlıklı olarak geniş zaman kipiyle ("Yer oturan kişi ile şereflener", "Yer bərk olanda öküz öküzdən görər”, "Yerin yeddi gatından keçir") kurulan atasözleri, bünyesinde barındırdığı hükümlerin her zaman geçerli olduğunu göstermektedir. "Vetene geldim imana geldim", "Yer ayrılsaydı yere girerdim” şeklinde geçmiş zaman kipiyle biten atasözleri ise, bu sözlerin uzun bir gözlem ve tecrübeye sahip kişiler tarafından söylendiğine işaret etmektedir. Bazı atasözleri de emir kipiyle kurulmaktadır: "Yurddan çıhsan da evden çıhma". Bunun yanı sıra "El gücü, sel gücü" gibi sadece durum bildiren atasözlerine de rastlanmaktadır.

Azerbaycan Türkçesinde kullanılan toprakla ilgili atasözlerini, ifade ettiklerine göre, dört ana başlık altında değerlendirmek mümkündür:

\subsection{Toprak ve yaşanılan yer (vatan) ilişkisini gösteren atasözleri}

2.2. Toprak ve insanın yaratılışı ilişkisini gösteren atasözleri

2.3. Toprak ve canlılık ilişkisini gösteren atasözleri

2.3. Toprak ve bolluk, bereket, zenginlik ilişkisini gösteren atasözleri

\subsection{Toprak ve yaşanılan yer (vatan) ilişkisini gösteren atasözleri}

Vatandan ayrı olmanın ne demek olduğunu iyi bilenlerden Azerbaycan Türklerinin atasözlerinde toprağın, özellikle yaşanılan yer (vatan) anlamının vurgulandığı görülmektedir. Aktaracağımız şu atasözü, vatan toprağı olan Karabağ'1, terk etmeye zorlanan Azerbaycan 
Türklerinin acısını açık bir şekilde ortaya koymaktadır: "Gürbet görmeyen adam veten gedri bilmez". "Veten doğmadır özge diyar ögey" diyerek vatanı öz, başka diyarları üvey olarak gören ve bir an önce ana vatana dönmek gerektiğine işaret eden Azerbaycan atasözü, "Veten virane de olsa, meseldir mehz cennetdir" ifadesiyle vatanın her şekilde cennet olduğunu ve değerini bilmek gerektiğini söylemektedir. Yine, “Qəribi vurmuşlar, 'Vay Vətən!' demiş”, ya da "Vetenin bir gışı gürbetin yüz baharından yahşıdır" şeklindeki atasözleri vatanın tüm güzelliklerden, zenginliklerden daha değerli olduğunu, insanın öz vatanından daha iyi bir yer bulamayacağını vurgulamaktadır.

Azerbaycan Türklerinin atasözlerinde toprak, yerine getirdiği işlevlerin önemi nedeniyle diğer tüm varlıklardan üstündür, kutsaldır. Öyle ki, "Ana kimi yar olmaz, vətən kimi dövlət” diyerek vatan toprağının değeri, kutsallı̆̆ı ile anne sevgisi eş tutulmaktadır. "Vetene mehebbet iman eseridir" diyerek vatana sevgi duymanın İslam dininin gerekliliklerinden olduğuna işaret eden atasözleri, bir yandan "El igidləri ilə tanınar" diyerek vatan toprağının da içinde yaşayan bireylerin güçleri, başarıları ve birliktelikleriyle tanınacağına vurgu yapmaktadır. "Vətənsiz olan kəfənsiz qalar", "Eli olmayanın, dili də olmaz" atasözleri, insanın hayatındaki en değerli, kutsal varlık olan vatan toprağına, bireyleri koruyup kollama ve kendini ifade etmelerine imkân sağlama görevi vermektedir. Bunun yanı sıra, "Yurddan çıxsan da, eldən çıxma!", "El içində - öl içində!” denilerek bir kişinin yaşadığı yerden, evinden ayrılsa ya da başka bir yere taşınsa da, kutsal vatan toprağını terk etmemesi gerektiği düşüncesi de öne çıkarılmaktadır.

Bireye vatanın, kendisinin evi olduğunu öğretmesi ve vatanını koruduğu takdirde kendi evini korumuş olacağını kavratması açısından vatana sahip çıkma sorumluluğu "Veten elin evidir", "El yandıran şamı söndürmek olmaz” atasözleri aracılığıyla aşılanmaya çalışılmaktadır. Vatan toprağını sevmenin birey ve toplumun temel değerleri arasında yer aldığı, aksi durumda hem bireyin hem de toplumun zarar göreceği, "Vetenin sevmeyen insan olmaz, olsa ol şehsde vicdan olmaz" denilerek vurgulanmaktadır. Bunun yanı sıra vatanından ayrı kalmayan kişilerin, vatanın kıymetini bilemeyeceği, "Qürbet görmeyen adam vətən qədri bilməz" şeklinde ifade edilmektedir. Yine vatan toprağından uzakta olanların, vatana duydukları özlem ve içinde bulundukları ruhsal durum, "Vətən yadına düşən qerib ağlamasın neyləsin?" atasözü ile dile getirilmektedir.

\subsection{Toprak ve insanın yaratılışı ilişkisini gösteren atasözleri}

Eski Türkler, kâinatta var olan beş unsurun su, ateş, ağaç, maden ve toprak olduğunu düşünmüş, toprağın, diğer unsurlar arasında merkez konumunda yer alması sebebiyle, farklılık arz ettiğini kabul etmişlerdir (Esin, 2001: 24-25). Türk mitolojisinde, her yer sularla kaplı iken, Tanrının emri ile Erlik, suyun dibinden toprak çıkarır. Bu toprak suyun üzerine atılarak yer ve tepeler meydana getirilir (Ögel, 1998: 451-453). Yunan mitolojisine göre, düzensiz boşluktan ilk önce Gaia (Toprak) çıkar ve evreni düzenleyerek göğü ve denizi yaratır (Hançerlioğlu, 2013: 516). Yani toprak, su altında, dünya yaratılmadan önce de vardır ve yaratılan nesnelerin ham maddesini oluşturmuştur (Taş, 2011: 91-93). İnsanın yaratılışında kullanılan bu hammadde kimi zaman doğrudan toprak kimi zaman çamur, kil ya da balçı gibi toprağın bir türevidir (Çağlar, 2008: 151). 
Azerbaycan Türklerinde toprak, insanın yaratıldığg ve öldükten sonra tekrar döneceği bir madde olarak algılandığı için Toprak Ana’ya büyük bir saygı gösterilmektedir. Carol Delaney'in "tohum ve tarla" kuramıyla işaret ettiği üzere erkek, tohumu verir, kadın ise tarla görevini yerine getirir. Toprak verimliyse hasatın bol olmaması için hiçbir sebep yoktur; ancak kısırsa ürün veremez (Delaney, 2001: 49-63). Toprağa yani yere, bir ana rolü yüklenmiş, dolayısıyla toprak; yer, kadın olarak algılanmış ve kendisine saygıyla Toprak Ana, Yer Ana denmiştir. "Torpağı bir yerden götürülüb” diyerek birbirine benzeyen, birbiriyle iyi anlaşan kişilerin aynı topraktan yaratıldığına vurgu yapan Azerbaycan atasözü bu duruma bir örnektir.

Kur'an-ı Kerim'de de insanın yaratılışına dair yapılan açıklamalarda, yaratılışın kaynağındaki temel maddenin toprak olduğu belirtilmektedir: "Hem Allah, sizi bir topraktan, sonra bir meniden yarattı" (Fâtır Sûresi, 11. ayet). "Ve O’nun (kudret) delillerindendir ki, sizi bir topraktan yarattı; sonra da siz şimdi bir 'beşer'siniz, (her tarafa) yayılıp duruyorsunuz" (Rûm Sûresi, 20.ayet). Bunun yanı sıra Kur'an-1 Kerim'de, ölümden sonra da insanın toprağa döneceği vurgulanır. Toprak, hem canlılara hem de ölülere kucak açar. Eliade bu durumu, "Yeryüzü Ana'nın faaliyetlerinin iki farklı dönemi" olarak değerlendirir. İnsanın topraktan yaratılması, toprağın kucağında yaşaması, ölümden sonra da toprağa gömülmesi "Yeryüzü Ana” kültüne bağlı dikkat çekici bir ritüeldir (Eliade, 2000: 252-255). "Böyüyün üzünə ağ olanı torpaq götürməz" diyen Azerbaycan atasözü büyüklerini dinlemeyen, onlara itaat etmeyen kimseyi toprağın dahi kabul etmeyeceğini belirtmektedir.

\subsection{Toprak ve canlılık ilişkisini gösteren atasözleri}

Farklı kültür ve inanışların buluştuğu ortak nokta; "yerin canlı olması” dır. "Yerden çıkan her şey yaşam doludur ve yere dönen her şey yeniden yaşam bulur" düşüncesi söz konusudur (Eliade, 2000: 196). Anasır-1 erbaa adı verilen ve kâinattaki oluşumu sağlayan dört unsurdan biri olan toprak, anne sıfatıyla koruyandır, kollayandır. Bu bakımdan bireyin hayatındaki önemi büyüktür. Kendi hatasıyla ya da başkalarının davranışı/sözü yüzünden utanma; utançtan kaybolma, yok olma arzusunu "Yer ayrılsaydı yere girerdim" diyerek ifade eden Azerbaycan atasözü, canlı olarak algılanan yerin aynı zamanda sığınılacak bir mekân olduğunu da belirtmektedir.

Orhun Yazıtları’nda ifade edildiği üzere, VIII. yüzyılda, Göktürklerde “yer-su”, devletin resmî kültlerinden biri olmuştur (Gökyay, 2000: CCXCII-CCXCIV; İnan, 1998: 491). Türklerde yer ve su, kutsallaştırılmış, onlara kişilik verilmiş, her çağda mukaddes ve saygın tutulmuşlardır (Ögel, 2002: 315-355; Eliade, 2000: 196). Öyle ki, “Torpağın garası üz ağardar" hükmünde bulunan atasözü, canlı bir unsur olan toprağın temizleyici özelliğine dikkat çekmektedir. Kur'an-1 Kerim'de, abdest almak için su bulunamadığı takdirde elleri toprağa sürerek teyemmüm yapmanın emredilmesi de bu doğrultuda düşünülebilir.

"Yer gulaglı olar", "Yerin də qulağı var" diyen Azerbaycan atasözleri, toprağı canlı bir unsur olarak algılamakta ve ağızdan çıkan sözün, iki kişi arasında gizli olarak konuşulsa dahi, sır olmaktan çıkacağını belirtmektedir. Bu bağlamda toprak, üzerinde yaşayan herkesin kulağı olarak tasavvur edilmektedir. 
Canlı olarak kabul edilen toprak unsurunun merkezî bir konumda olduğu sembolik nitelikte birçok inanış, ritüel ölüm etrafında kümelenmiştir (Eren, 2012: 260). "Torpaq deyer: - Öldür məni, dirildim səni!” diyen Azerbaycan atasözünde toprağın karnını yarmaktan, yararak, keserek simgesel anlamda öldürmekten söz edilmektedir. Karnı yarılarak simgesel olarak öldürülen toprak diriltmektedir.

\subsection{Toprak ve bolluk, bereket, zenginlik ilişkisini gösteren atasözleri}

Toprak, dünya üzerinde yaşanılan yer, var oluştaki temel madde olmasının yanı sıra hayatı devam ettirebilmek için gerekli olan besinleri bünyesinden çıkarır, çünkü üretkendir (Eliade, 2000: 255). "Çörəyi torpaqdan al, özgənin ağzından yox" diyen Azerbaycan atasözü, temel gıda maddelerinin sadece topraktan alınabileceğini ifade etmektedir.

Toprağın, bünyesinde barındırdığı bolluk, bereket ve zenginliği sınırsız bir şekilde insanlara sunması, toprakla insan arasındaki karşılıklı ilişkiye göre şekillenmektedir. Bakılmayan, işlenmeyen toprak kuruyup çölleşerek, bireyin ve hatta dünyanın sonunun yakın olduğunu gösterir. İşlenen toprağın ürün vermesi, "yaratılışın simgesel tekrarı" olarak görüldüğü için toprağa saygı eski dönemlere kadar uzanmaktadır (Eliade, 1994: 71). Nitekim "Torpağ1 sanı yaşayasan”, “Torpağa bah deyipler” diyen Azerbaycan atasözleri, insanın toprağa hürmet ettiği takdirde ayakta kalabileceğine vurgu yapmaktadır. Yine, "Dağlar qarıynan, torpaq varıynan” şeklindeki atasözü toprağın, ekilip biçilip zenginleştirildiği takdirde daha değerli olacağını söylemektedir.

Azerbaycan Türklerinin atasözleri, “Torpag ovuclayan gızıl ovuclar”, “Torpagnan oynayan ac galmaz" diyerek toprağı işlemenin bireyleri, dolayısıyla toplumu, memnun edeceğini belirtmektedir. Benzer şekilde, “Torpaq deyər: - Sən mənə tər ver, mən sənə zər verim!” diyen atasözü, toprağın, onunla uğraşan kişinin zahmetiyle, emeğiyle ziynetleneceğini ifade etmektedir. Şu atasözü ise toprağın ne kadar değerli bir hazine olduğunu ancak ona emek veren ve bu yolda alın teri döken kişilerin anlayabileceğini belirtmektedir: "Torpağın sirrini eli torpagda olandan sor".

“Torpag gızıl guşdur, elden burahdın uçar geder” diyen Azerbaycan atasözü, emek verilmediği, ilgilenilmediği takdirde toprağın bireye ve topluma herhangi bir faydasının olmayacağını, aksine elden uçup gideceğini söylemektedir. Değerli bir hazine, yaşamın, hayatın kaynağı olan toprağın elden gitmesi ise, bireylerin ve toplumun ekonomik anlamda başkalarına bağımlı bireyler olarak yaşamalarına yol açacaktır. Bu noktada, "Yer beyin, yurt hanın, işle ha çıhsın canın" şeklindeki atasözü bireylere, üzerinde yaşadıkları topraklar için çok çalışmaları, emek vermeleri gerektiğini söylemektedir.

"Yer yiyəsiz qalanda, donuz təpəyə çıxar" diyen Azerbaycan atasözü, sahipsiz ve bakımsız kalan toprağın kültürel olmaktan çıkıp vahşileşeceğini, vahşi hayvanlara mekân olacağını ifade etmektedir. Üretken bir varlık olması, işlendiği, emek verildiği takdirde bitmeme ve tükenmeme özelliği nedeniyle toprak, mecazi anlamda ölüm konusunu bünyesinde barındıran atasözlerinde de yer almaktadır. Öyle ki, "Gözü ancaq torpaq doyurar” hükmünde bulunan atasözü, kendisinde olan şeylerle yetinmeyen, açgözlü kişinin ancak toprağa gömüldükten sonra tatmin olabileceğini vurgulamaktadır. 
"Yer-su" kültüyle bağlı koruyucu ruhlar olan "izi / iye (yiye / eye)" anlayışı (İnan, 2000: 41; Beydili, 2003: 129-130) da Azerbaycan Türklerinin atasözlerinde dile getirilmektedir. "Yer yiyəsini sanı" diyerek yerin, "sahipsiz" ve "koruyucusuz" olmadığı belirtilmekte, kendisine saygı duyulması gerektiği vurgulanmaktadır. Türk mitolojisinde hayatın ve canlılığın kaynağı olarak kabul edilen, kutsal sayılan yerin de kendi iyesi olduğuna dair inanç, birçok Türk boyunda olduğu gibi, Azerbaycan Türkleri arasında da yaşamaktadır.

Yaşamın devamını sağlayan hayati unsurlardan olan toprak; Azerbaycan Türklerinin atasözlerinde bereket, bolluk ya da üretkenlik, kavramlarıyla birlikte anılmakta, benzetmelere konu olmaktadır. "Torpag kimi bereketli ol ki hamının sevimlisi olasan", "Yer ekenindir, biçin biçenin" diyen Azerbaycan atasözleri, birey ve toplum hayatı için üretkenliğin önemine vurgu yaparak, bireyleri üretken olmaya teşvik etmektedir.

\section{Sonuç}

Ait olduğu toprağın, temel değer ve yargılarını, düşünce sistemlerini, din ve ahlâk anlayışlarını belli bir uyum ve düzen içerisinde işlemesi noktasında, yukarıdaki örneklerden de anlaşılacağı üzere, Azerbaycan Türklerinin atasözleri önemli bir rol üstlenmektedirler. Bireyle topluma toprağı nasıl algılaması, değerlendirmesi, toprağa nasıl yaklaşması, ne şekilde davranması, toprakla ilgili nelerden kaçınması ve nelere dikkat etmesi gerektiğini öğretip hatırlatan, örnek ve ideal davranış modelleri sunan atasözlerinin söz konusu işlevi, Azerbaycan Türklerinin atasözlerinde açık bir şekilde görülmektedir. Toprak olgusu üzerinde duran atasözlerinin çeşitliliği dikkate alındığında, Azerbaycan Türklerinin atasözleri, toprağın yaşamın bir parçası olması noktasında önemli bir görevi yerine getirmektedir. Bu bağlamda, toprak konulu atasözlerinin Azerbaycan Türklerinin duruş, tavır ve zihniyetleri hakkında da birtakım bilgiler verdiğini söylemek mümkündür.

Azerbaycan Türklerinin toprakla ilgili atasözleri, bireye ve topluma yaşanılan yer (vatan) anlamını kavratma noktasında yoğunlaşmaktadır. Bunun yanı sıra toprağın, canlı bir unsur olarak algılanması, bolluk, bereket, zenginlik kaynağı olması, toprağı işlemenin gerekliliği konularına yönelik aktarımlar da vurgulanmaktadır. Bu açıdan bakıldığında, Azerbaycan Türklerinin toprak temalı atasözlerinde, vatanın güzelliği, kutsallığı, vatana sahip çıkmak gerektiği, vatandan ayrı kalma acısı, toprağa emek vermek gerektiği konuları daha ön plandandır. Toprak denince, özellikle vatan sevgisi ve gurbet konularına atasözlerinde değinilmektedir. Anavatanın işgal edilmesiyle birlikte hürriyetlerini kaybedip, yıllarca vatansız, esaret altında yaşayan Azerbaycan Türklerinin bağımsızlık ve vatan özlemlerinin, atasözlerinde geniş yer bulması son derece doğaldır.

Azerbaycan atasözleri, Azerbaycan Türklerinin toprak olgusu üzerine uzun gözlem ve deneyimleri sonrasında oluşturdukları temel yargılarıyla bu yargılara bağlı ilkelerini, edebi sanatların desteğini de arkasına alarak, etkili bir şekilde ortaya koymuştur. Azerbaycan atasözleri toprağın, yukarıda anılan işlevleri esasında, birey ve toplum hayatındaki önem ve değerinin sürdürülmesi adına, edebî bir üslupla hatırlatmalarda bulunmuştur. Bu noktada atasözlerinin, kısa ve kalıplaşmış olmaları, kolay akılda kalmasına, ezberlenip aktarılmasına imkân sağlamıştır. Söz konusu temel yargı ve ilkelerin, ağırlıklı olarak geniş zaman kipiyle ifade edilmiş olması da, her zaman geçerli olduklarına işarettir. 


\section{Kaynaklar}

Ercilasun, A. B. (Komisyon Başkan1). (1991). Karşılaştırmalı Türk lehçeleri sözlüğü. (Cilt I). Ankara: Kültür Bakanlığı.

Akalın, Ş. H. (Çalışma Grubu Başkanı). (2011). Türkçe sözlük. 11. Baskı. Ankara: Türk Dil Kurumu. Abdulla, B. (2001). Azarbaycan şifahi xalq adəbiyyatı (Antologiya). Birinci kitab. Bakı: XXI- Yeni Nəşrlər Evi.

Aça, M. (2009). Türk halk edebiyatında tür ve şekil bilgisi. Editör: Ceylan, Ö., Başlangıçtan günümüze Türk edebiyatında tür ve şekil bilgisi (ss. 447-526). İstanbul: Kriter.

Aça, M. (2011). Tıva atasözleri. Karadeniz/Black Sea/Çornoe More, S. 12, ss. 29-50.

Aksoy, Ö. A. (1984). Atasözü ve deyimler sözlüğü I Atasözleri sözlüğü. Ankara: Türk Dil Kurumu.

Altaylı, S. (2010). Atasözü ve deyimler arasındaki farklar. Karadeniz Araştırmaları Dergisi, 7 (25), ss. $125-134$.

Arat, R. R. (2008). Kutadgu Bilig Yusuf Has Hacib. İstanbul: Kabalc1.

Atalay, B. (2013). Kâşgarlı Mahmud Divanü Lûgat-it-Türk (Çeviri). Birleştirilmiş birinci bask1 (Cilt III). Ankara: Türk Dil Kurumu.

Beydili, C. (2003). Türk mifoloji sözlüyü. Baku: "Elm”.

Bəydili (Məmmədov), C. (2004). Atalar sözü. Bakı: Öndər Nəşriyyat.

Boratav, P. N. (1988). 100 soruda Türk halk edebiyatt. İstanbul: Gerçek.

Clauson, S. G. (1972). An etymological dictionary of pre-thirteenth century Turkish. London: Oxford University.

Çağlar, B. (2008). Türk mitolojisinde dört unsur ve simgeleri üzerine bir inceleme. Kocaeli Üniversitesi Sosyal Bilimler Enstitüsü, basılmamış yüksek lisans tezi, Kocaeli.

Çobanoğlu, Ö. (2004). Türk dünyası ortak atasözleri sözlüğü. Ankara: Atatürk Kültür Merkezi.

Delaney, C. (2001). Tohum ve toprak (Çev.: S. Somuncuoğlu ve B. Aksu). İstanbul: İletişim.

Elçin, Ş. (1993). Halk edebiyatına giriş. Ankara: Akçağ.

Elçin, Ş. (1997). Türk dilinde atalar sözü (Kelime, kavram, bibliyografya, örnekler). Halk Edebiyatı Araştırmaları (Cilt II) (ss. 413-424). Ankara: Akçağ.

Eliade, M. (1994). Ebedi dönüş mitosu. (Çev.: Ü. Altuğ), İstanbul: İmge.

Eliade, M. (2000). Dinler tarihine giriş. (Çev.: L. Arslan), İstanbul: Kabalcı.

Eren, M. (2012). Türk kültüründe ölüm ve toprakla ilgili inanış ve ritüeller. Acta Turcica Çevirimiçi Tematik Türkoloji Dergisi, IV (1), ss. 259-271.

Ergin, M. (2000). Orhun abideleri. İstanbul: Boğaziçi.

Esin, E. (2001). Türk kozmolojisine giriş. İstanbul: Kabalc1.

Gökyay, O. Ş. (2000). Dedem Korkudun kitabı. İstanbul: Milli Eğitim Bakanlığı.

Gülensoy, T. (2011). Türkiye Türkçesindeki Türkçe sözlüklerin köken bilgisi sözlüğü-Etimolojik sözlük denemesi- (Cilt II). Ankara: Türk Dil Kurumu.

Hançerlioğlu, O. (2013). Dünya inançları sözlüğü. İstanbul: Remzi.

İnan, A. (1998). Türklerde su kültü ile ilgili gelenekler. Makaleler ve incelemeler (Cilt I) (ss. 491-495).

Ankara: Türk Tarih Kurumu.

İnan, A. (2000). Tarihte ve bugün şamanizm materyaller ve araştırmalar. Ankara: Türk Tarih Kurumu. Kasapoğlu Akyol, P. (2012). Kullanım şekilleri ve geleneğiyle kültürümüzde toprak. Acta Turcica Çevirimiçi Tematik Türkoloji Dergisi, IV (1), ss. 316-333.

Korkmaz, E. (2004). Zerdüştlük terimleri sözlüğü. İstanbul: Anahtar. 
Malinowski, B. (1992). Bilimsel bir kültür teorisi. (Çev.: S. Özkal), İstanbul: Kabalc1.

Orucov, Ә. ve diğ. (2006). Azərbaycan dilinin izahlı lüğəti (Cild I). Bak1: "Şərq-Qərb".

Oy, A. (1972). Tarih boyunca Türk atasözleri. İstanbul: Türkiye İş Bankası.

Ögel, B. (1998). Türk mitolojisi (Kaynaklar ve açılklamalart ile destanlar) (Cilt I). Ankara: Türk Tarih Kurumu.

Ögel, B. (2002). Türk mitolojisi (Kaynaklar ve açıklamaları ile destanlar) (Cilt II). Ankara: Türk Tarih Kurumu.

Öztürk, G. (1993), Azerbaycan atasözleri ve deyimleri (Metin-tercüme-indeks). Marmara Üniversitesi Türkiyat Araştırmaları Enstitüsü, Basılmamış yüksek lisans tezi, İstanbul.

Schimmel, A. (2002). Tanrı'nın yeryüzündeki işaretleri. (Çev.: E. Demirli), İstanbul: Kabalcı.

Taş, İ. (2011). Türk düşüncesinde kozmogoni-kozmoloji. Konya: Kömen. 